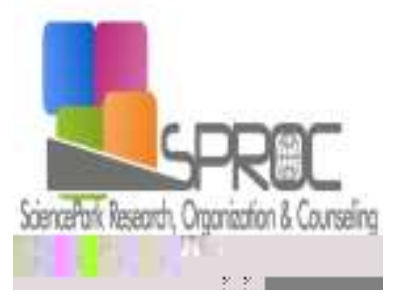

\section{New Trends and Issues Proceedings on Humanities and Social Sciences}

Volume 4, Issue 1 (2017) 691-699
'New Trends and Issues Proceedings on Humanities and Social Sciences

\title{
A study of foreign students' intercultural experiences at Lithuanian University of educational sciences
}

Jolanta Lasauskiene ${ }^{{ }^{*}}$, Faculty of Education, Lithuanian University of Educational Sciences, Studentų St. 39, LT08106 Vilnius, Lithuania.

\section{Suggested Citation:}

Lasasuskiene, J. (2017). A study of foreign students' intercultural experiences at Lithuanian University of educational sciences.

[Online].

4(1), pp 691-699. Available from: www.prosoc.eu

Selection and peer review under responsibility of Prof. Dr. Jesus Garcia Laborda, University of Alcala, Spain.

${ }^{\circ} 2017$ SciencePark Research, Organization \& Counseling. All rights reserved.

\begin{abstract}
In different cultural context integration into academic and socio-cultural life of a university, language and other differences impose serious problems on each foreign student. Successful adaptation of the newly admitted students in a different cultural context is treated as one of the prerequisites for development of intercultural competence. The purpose of this study is to reveal the experience of foreign students, which is related to developing intercultural competence of pre-service music teachers. A qualitative research strategy was chosen for this study, using semi-structured written student reflections. The sample of the research included 36 foreign Master's degree students (Chinese), who chose studies at Lithuanian University of Educational Sciences (Music Education). The results of qualitative content analysis as an outcome of qualitative diagnostics have revealed the factors (educational, psychological, cultural, individual) influencing intercultural competence of future music educators (foreign students). The research was carried out in 2014-2016.
\end{abstract}

Keywords: Foreign student, future music educator, intercultural competence, experiences, reflection.

* ADDRESS FOR CORRESPONDENCE: Jolanta Lasauskiene, Faculty of Education, Lithuanian University of Educational Sciences, Studentų St. 39, LT-08106 Vilnius, Lithuania. 
Lasasuskiene, J. (2017). A study of foreign students' intercultural experiences at Lithuanian University of educational sciences.

\section{Introduction}

The rapid process of globalization poses serious challenges in developing intercultural competence (Portera, 2014; Spitzberg \& Changon, 2009). An intercultural dialog and communication in multicultural environment become the most appropriate way of democratic communication (Galkin et al., 2015). The aforementioned competence is particularly significant to music educators evaluating current changes in global society, perception of culture and educational environment.

The trends in international development of higher education are best reflected in international openness (The Order of the Minister of Education and Science of the Republic of Lithuania "On the Approval of the Action Plan for 2013-2016 on the Promotion of the Internationality of Higher Education", 2013). The trends in higher education development are best expressed in the constantly growing demand for higher education all over the world. Internationalisation is one of the key priorities in development of higher education in the European Union countries. Next to the aims of mobility promotion, the implementation of joint study programmes and development of study programmes in foreign languages as well as collaboration with other world regions are applied. The process of study internationalisation necessitates globally engaged and interculturally competent music teacher education (Zhang, 2016).

Learning abroad is not only a physical change of the environment for a student but also overstepping of geographical, cultural, social, intellectual and emotional limits (Cushner, 2009). Successful process of learning abroad is linked with favourable educational environment (Douglas et al., 2014; Russell et al., 2010). In the beginning of their studies at a foreign higher education institution students have to cope with numerous challenges, such as language difficulties, visa applications, financial pressures, accommodations. They have to adapt to requirements of the new institution and the new learning environment, changed social relations, to perceive themselves as a member of a new community and to establish value-based relation with the institution (Sheridan, 2011). The process of adaptation as well as the quality of studies are defined by certain academic standards (objective criteria) and compliance of academic services with the students' needs, which evokes their (subjective) satisfaction (Maunder et al., 2013). Researchers interested in cross-cultural adaptation have examined the psychological phases people go through when entering a foreign culture, the traits that contribute to adjustment in a new culture, and the process of becoming an intercultural individual (Staley, 2014).

Many research studies on intercultural competence have been conducted all over the world lately (Portera, 2014; Spitzberg \& Changon, 2009). Despite the abundance of studies on intercultural competence, Lithuania lacks research that aims to analyse the experience of foreign students as representatives of alien cultural, social and institutional context, which enables to better learn and reveal the role of aforementioned factors analysing the development of intercultural competence (Barton et al., 2015; Virgailaite-Meckauskaite, 2011). The current research targets at contribution to empirical data accumulation studying the aspects of the problem, which has been underresearched in Lithuania, i.e. the importance of integrating personal experience (feelings, behavioural or learning difficulties) of a foreign student developing intercultural competence at university. The article presents one part of the longitudinal inquiry, which serves as basis revealing peculiarities of developing intercultural competences in music education studies.

\subsection{Problem statement}

Therefore, the research problem is formulated as the following research question: how foreign students reveal (self-) development of intercultural competence reflecting on their personal 
Lasasuskiene, J. (2017). A study of foreign students' intercultural experiences at Lithuanian University of educational sciences.

[Online]. 4(1), pp 691-699. Available from:

www.prosoc.eu

experiences and what factors and conditions would increase possibilities of (self-) development of their intercultural competence?

\subsection{Purpose of study}

The purpose of study is to reveal the peculiarities of developing intercultural competence of foreign students (future music educators) by reflecting their personal experiences.

\section{Methods}

\subsection{Sample}

The sample of the research consisted of 22 first and 14 second year Master's degree students (Chinese), who chose studies at Lithuanian University of Educational Sciences (Music Education). The duration of foreign students' academic experience differs: from 6 months (students enrolled this academic year) to 1,5 years (students already living in Vilnius and studying in Lithuanian University of Educational Sciences). The students participating in the study ( 23 females and 13 males) were coded as S1, S2, S3......and S36.

\subsection{Data collection}

A qualitative research strategy, using individual semi-structured written student reflections, was applied (Rushton \& Suter, 2012). The reflection encompasses the methods of introspection and retrospection that are of particular importance for revealing one's personal experience in a different socio-cultural context of a new country (Boucenna \& Charlier, 2013). The research participants were free to choose the number of such situations to describe and to provide specific examples.

\subsection{Data analysis}

The content of the written reflections was analysed on the basis of qualitative content analysis (Mayring, 2014). It is stated that the text provided by the participants in the research is considered as the material for qualitative content analysis, which represents the process of reflection regarded as an essential aspect of experiential learning. The obtained results allow to identify peculiarities of the specific context, where the research participant is active in, and to establish the needs for development of competencies on the basis of the above mentioned. The research ethics was grounded on the principles of goodwill, voluntarism and confidentiality (Miller et al, 2012).

\subsection{Limitations of the qualitative research}

The limitation of this research is that the non-probability sample was chosen and the obtained results cannot be generalised but they are useful disclosing the possibilities and variety of development of intercultural competence.

\section{Results and Discussion}

Upon the analysis of the students' reflections on their international experiences, 4 qualitative categories (educational, psychological, cultural, individual factors) were distinguished, which can be subdivided into two groups (themes) - positive and negative experience acquired in Lithuania (see: Table 1). 
Lasasuskiene, J. (2017). A study of foreign students' intercultural experiences at Lithuanian University of educational sciences.

[Online]. 4(1), pp 691-699. Available from:

www.prosoc.eu

Table 1. Results of Analysis of Foreign Students' Written Reflections

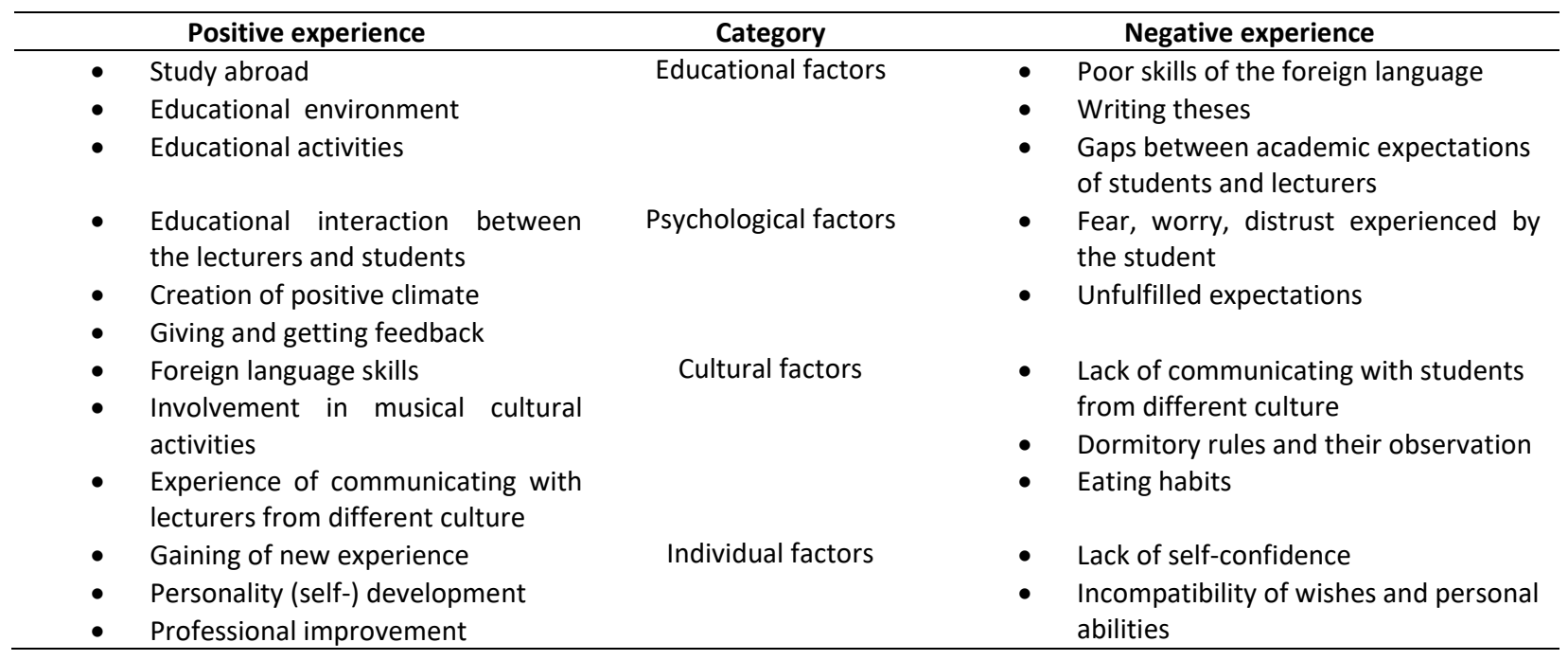

\subsection{Positive Experience of (Self-) development of Foreign Students' Intercultural Competence}

The educational system, which empowers students' studying, embraces competency-based, psychological, didactic, organisational and material conditions. It was determined that intercultural competence was largely affected by the educational factors, such as studies abroad, an educational environment, as well as educational activities. It is clear that foreign students, who study in Lithuanian University of Educational Sciences, encounter new kind of academic activity organisation, new learning methods and roles of students and lecturers:

S1

S8

S21

S30

In the category "Psychological factors" three sub-categories are singled out: educational interaction between the teacher and students, creation of positive climate, giving and getting feedback. Analysing the experiences acquired by foreign students during their studies in Lithuania, the importance of lecturer-student interaction to development of intercultural competence was revealed:

S3

S18 
It is likely that partnership communication (based on creativity and interactivity) with lecturers may have influence on deeper expression of intercultural competence of foreign students.

The following sub-categories were singled out in the category "Cultural factors": foreign language skills, involvement in musical cultural activities, ability to communicate with representatives of other culture. Foreign students acknowledge that:

It is obvious that the use of foreign language has become a real challenge to students. Seeking to attain higher academic results and to join the new culture, linguistic competency becomes essential (Virgailaite-Meckauskaite, 2011). Though foreign students evaluate their foreign language skills rather low, seriously learning students significantly improved their English language skills at the end of their studies.

Involvement in musical cultural activities is linked with activities that focus on personal and professional needs (Wang, 2016). It can be assumed that active musical cultural activities encouraged students to get acquainted with culture of another country as if "from inside", i.e. through the experience of musical cultural activity: 
Lasasuskiene, J. (2017). A study of foreign students' intercultural experiences at Lithuanian University of educational sciences. [Online]. 4(1), pp 691-699. Available from:

www.prosoc.eu

The category "Individual factors" contains three sub-categories: gaining of new experience, increase of professional motivation, personality (self-) development and professional improvement. It should be noted that learning of a foreign country occurs through the values internalised in own culture, which enable foreign students to obtain new experience linking and comparing own cultural values, attitudes and behaviour patterns with those of foreign culture identifying and acknowledging differences:

S4

S12

S19

S31

According to foreign Master's degree students learning in Lithuania, a music educator, who seeks to improve and successfully adapt in contemporary multicultural society, has

Students think that it is very important " and

\subsection{Expression of Negative Experiences of (Self-) developing Intercultural Competence of Foreign Master's Degree Students}

The study found that, in adapting to the new academic environment, the foreign (Chinese) students at Lithuanian University if Educational Sciences encountered various academic, cultural and daily life difficulties, such as language barriers, writing theses, student dormitory regulations and their observation and eating habits. However, it is necessary to emphasise that only a very small number of students associate own experiences with negative experiences. According to Ting-Toomey (2009), intercultural conflicts arising from the lack of intercultural competence (differences between the groups and their socio-cultural misunderstanding). Students encounter interculturally incompetent behaviour, especially in relation to the affective dimension of intercultural competence, and it is a lack of intercultural sensitivity, adaptability and empathy (Lukesová, 2015).

Having coped with the aforementioned situations, the foreign students acquired experience in solving the encountered intercultural problems and consolidated their intercultural competence:

S3

S11

S17

S29 
Lasasuskiene, J. (2017). A study of foreign students' intercultural experiences at Lithuanian University of educational sciences.

www.prosoc.eu

The foreign students went through the period of adpatation to the alien cultural medium in a different way (Russell et al., 2010):

S5

S13

The foreign students indicated the major challenges encountered during their studies in Lithuania - poor foreign language skills and writing t8enttl13 Tc[(: )] TJETBT850 0173.584490 .99 Tm[( )]TR4 5.664512 .594442 
Lasasuskiene, J. (2017). A study of foreign students' intercultural experiences at Lithuanian University of educational sciences. [Online]. 4(1), pp 691-699. Available from:

www.prosoc.eu

Generalising, it is possible to state that the case of intercultural competence development of music educators (foreign Master's degree students) chosen for analysis is only one in the context of professional training. It is worth mentioning that the study subject of music education is very distinctive and distinguished by specific methods of artistic-musical world cognition. Therefore, intercultural competence of music educator acquires specific features both due to specifics of artistic expression and their links with educational activities. They predetermine peculiarities of (self-) development of intercultural competence.

\section{Conclusions}

Studies abroad are considered to be a priority educational factor for developing intercultural competence of foreign students (future music educators), which encourages learning of other cultures, confirms importance of foreign language skills and opens a path towards personal and professional improvement. Such studies are best consistent with situations and problems of real intercultural encounters and, therefore, development of intercultural competence can be expected. Targeted organisation of the educational process in the host institution and the cultural contexts of the host country acquire utmost importance.

It was determined that intercultural competence was largely affected by educational, psychological, cultural and individual factors. Generalising experiences gained by the Master's degree students foreigners (future music educators') the academic environment and participation in musical cultural activities has the most considerable impact on intercultural competence development of music educators.

The research revealed experienced problem situations (academic, cultural, daily life) of foreign students, which appeared during studies in real environments of intercultural interaction. The most significant challenges regarding academic studies in a foreign educational institution are related to poor skills of foreign languages and writing theses.

Following the research results, it can be stated that educational environment in Lithuanian University of Educational Sciences is sufficiently oriented towards the contemporary learning paradigm and empowers foreign students to develop their intercultural competence. The revealed educational factors make the basis for the development of intercultural competence of pre-service music teachers and further scientific investigation. 
Lasasuskiene, J. (2017). A study of foreign students' intercultural experiences at Lithuanian University of educational sciences.

[Online]. 4(1), pp 691-699. Available from:

www.prosoc.eu

\section{References}

Aukstojo mokslo tarptautiskumo skatinimo 2013-2016 metų veiksmų planas. (2013).

(The Order of the Minister of Education and Science of the Republic of Lithuania On the Approval of the Action Plan for 2013-2016 on the Promotion of the Internationality of Higher Education, 2009 2013, No. V-878). Available online at: http://www.smm.lt/web/lt/teisesaktai/tei/ministro-isakymai

Barton, G. M., Hartwig, K. A. \& Cain, M. (2015). International students' experience of practicum in teacher education: An exploration through internationalisation and professional socialisation.

(8), 149-163.

Boucenna, S. \& Charlier, E. (2013). Reflective practice in the teaching profession: The case of training and research practices in the French community in Belgium.

321-338.

Cushner, K. (2009). The Role of Study Abroad in Preparing Globally Responsible Teachers. In: R. Lewin (ed.), (pp. 151-169) NY: Routledge.

Douglas, J., Douglas, A., McClelland, R. \& Davies, J. (2014). Understanding student satisfaction and dissatisfaction: an interpretive study in the UK higher education context. Available online at: http://dx.doi.org/10.1080/03075079.2013.842217

Galkin, D. V., Pogukaeva, N. V., Ageeva, V. V. \& Nikolaeva, A. M. (2015). Intercultural environment as a competitive advantage of higher education system. 61. doi: http://dx.doi.org/10.18844/cerj.v5i2.235

Lukesova, M. (2015). The analysis of intercultural conflicts between students of tertiary education. $174,1457-1464$.

Maunder, R. E., Cunliffe, M., Galvin, J., Mjali, S. \& Rogers, J. (2013). Listening to student voices: Student researchers exploring undergraduate experiences of university transition.

, (2), 55ring, P. (2014).

Monograph. Available online at: http://nbn-resolving.de/urn:nbn:de:0168-ssoar-395173

Miller, T., Mauthner, M., Birch, M. \& Jessop, J. (2012).

Portera, A. (2014). Intercultural competence in education, counselling and psychotherapy.

, (2), 157-174.

Rushton, I. \& Suter, M. (2012). Press.

. McGraw-Hill: Open University

Russell, J., Rosenthal, D. \& Thomson, G. (2010). The international student experience: Three styles of adaptation , 60(2), 235-249.

Sheridan, V. (2011). A holistic approach to international students, institutional habitus and academic literacies in an irish third level institution.

$62(2), 129-140$.

Spitzberg, B. \& Changon, G. (2009). Conceptualizing intercultural competence. In D. Deardorff (Ed.).

Staley, K. (2014).

(pp.2-52). Thousand Ouks, CA: SAGE.

. Colombia: Universidad del Norte.

Ting-Toomey, S. (2009). Intercultural conflict competence as a facet of intercultural competence development. In Deardorff, D.K. (ed.).

Virgailaite-Meckauskaite, E. (2011).

Doctoral Dissertation Social Sciences, Education (07 S).

Summary of the

Wang, X. (2016).

(Unpublished master thesis). Lithuanian University of Educational Sciences, Lithuania.

Zhang, I. (2016). thesis). Lithuanian University of Educational Sciences, Lithuania.

Zhang, W. (2009).

(Unpublished master thesis). Institute for Educational Research Faculty of Education, University of Oslo, Norway.

Zhou, Y. F. \& Todman, J. (2008). Patterns of adaptation of Chinese postgraduate students in the United Kingdom.

(3), 3-20. 